OPEN

SUBJECT AREAS:

CLIMATE-CHANGE

ECOLOGY

SUSTAINABILITY

SOIL MICROBIOLOGY

MICROBIAL ECOLOGY

Received

8 April 2013

Accepted

17 February 2014

Published

6 March 2014

Correspondence and requests for materials should be addressed to

Y.P.C. (chenyp@ ieecas.cn)

\section{Responses of soil microbial activity to cadmium pollution and elevated $\mathrm{CO}_{2}$}

\author{
Yi Ping Chen', Qiang Liv' ${ }^{1}$, Yong Jun Liv ${ }^{3}$, Feng An Jia' \& Xin Hua He${ }^{4}$ \\ ${ }^{1}$ SKLLQG, Institute of Earth Environment, Chinese Academy of Sciences, $X_{i}$ 'an 710075, China, ${ }^{2}$ University of Chinese Academy of \\ Sciences, Beijing 100049, China, ${ }^{3}$ College of Environmental Science, $X_{i}$ 'an University of Architecture and Technology, Xi'an \\ 710062, China, ${ }^{4}$ Elizabeth Macarthur Agricultural Institute, Department of Primary Industries, Menangle, NSW 2568, Australia.
}

To address the combined effects of cadmium (Cd) and elevated $\mathrm{CO}_{2}$ on soil microbial communities, DGGE (denaturing gradient gel electrophoresis) profiles, respiration, carbon $(\mathrm{C})$ and nitrogen $(\mathrm{N})$ concentrations, loessial soils were exposed to four levels of Cd, i.e., $0\left(\mathrm{Cd}_{0}\right), 1.5\left(\mathrm{Cd}_{1.5}\right), 3.0\left(\mathrm{Cd}_{3.0}\right)$ and $6.0\left(\mathrm{Cd}_{6.0}\right) \mathrm{mg} \mathrm{Cd} \mathrm{^{-1 }}$ soil, and two levels of $\mathrm{CO}_{2}$, i.e., $360\left(\mathrm{aCO}_{2}\right)$ and $480\left(\mathrm{eCO}_{2}\right) \mathrm{ppm}$. Compared to $\mathrm{Cd}_{0}, \mathrm{Cd}_{1.5}$ increased fungal abundance but decreased bacterial abundance under both $\mathrm{CO}_{2}$ levels, whilst $\mathrm{Cd}_{3.0}$ and $\mathrm{Cd}_{6.0}$ decreased both fungal and bacterial abundance. Profiles of DGGE revealed alteration of soil microbial communities under $\mathrm{eCO}_{2}$. Soil respiration decreased with $\mathrm{Cd}$ concentrations and was greater under $\mathrm{eCO}_{2}$ than under $\mathrm{aCO}_{2}$. Soil total $\mathrm{C}$ and $\mathrm{N}$ were greater under higher $\mathrm{Cd}$. These results suggest $\mathrm{eCO}_{2}$ could stimulate, while Cd pollution could restrain microbial reproduction and $\mathrm{C}$ decomposition with the restraint effect alleviated by e $\mathrm{CO}_{2}$.
$\Lambda$ tmospheric carbon dioxide $\left(\mathrm{CO}_{2}\right)$ concentration has increased from 280 to $380 \mathrm{ppm}$ since the industrial revolution and is projected to reach 420 to $936 \mathrm{ppm}$ at the end of $21^{\text {th }}$ century depending on scenarios ${ }^{1}$. The rapid increase of $\mathrm{CO}_{2}$ has drawn much attention because it closely relates to global climate change. Most of the attention has focused on the responses of aboveground and belowground processes as elevated $\mathrm{CO}_{2}$ $\left(\mathrm{eCO}_{2}\right)$ impacts numerous biogeochemical processes in both natural and agricultural ecosystems ${ }^{1,2}$.
Soil organic carbon (SOC) pool is three times greater than $\mathrm{C}$ stored in the atmosphere or vegetation biomass ${ }^{2}$. It is therefore imperative to understand how $\mathrm{eCO}_{2}$ impacts soil $\mathrm{C}$ dynamics and the associated underlying mechanisms. Studies have demonstrated that $\mathrm{eCO}_{2}$ could affect soil microbial communities, $\mathrm{C}$ and nitrogen $(\mathrm{N})$ cycling processes ${ }^{3-5}$. However, how $\mathrm{eCO}_{2}$ could affect $\mathrm{C}$ and $\mathrm{N}$ dynamics is of much uncertainty as the responses of soil microbial communities to $\mathrm{eCO}_{2}$ could be positive, negative or neutral ${ }^{6-10}$.

Soil microorganisms play vital roles in soil C and $\mathrm{N}$ transformations and nutrient cycles and thus affect soil biological, chemical, and physical properties. For instance, the activity of soil microorganisms and microbial community composition determine not only soil C sequestrations and emissions, and the decomposition and accumulation of soil organic matter ${ }^{11,12}$, but also $\mathrm{N}_{2}$-fixation, nitrification and denitrification, and the accumulation of plant available $\mathrm{NH}_{4}{ }^{+}$and $\mathrm{NO}_{3}{ }^{-13}$. However, limited information is available to the effect of $\mathrm{eCO}_{2}$ on soil bacterial and fungal abundance, community structure, and in turn $\mathrm{C}$ and $\mathrm{N}$ dynamics.

Furthermore, global climate change like elevated $\mathrm{CO}_{2}$ is happening along with other environmental issues, including heavy metal pollution, which has become a seriously global problem due to anthropogenic activities, such as mining, smelting, and sewage sludge disposal ${ }^{14}$. Unlike some organic contaminants, heavy metals are often accumulated in living organisms and not biodegradable in the environment. Many heavy metals, including cadmium (Cd), are toxic to soil microbes, which affect soil biogeochemical processes, such as soil organic matter (SOM) decomposition, through altering microbial biomass and activity ${ }^{1,15}$. Under climate change, the effects of $\mathrm{Cd}$ on soil microbial activity may become more complex as potential interactions between climate factors and excessive $\mathrm{Cd}$ in soil. However, the interactive consequence of $\mathrm{CO}_{2}$ and $\mathrm{Cd}$ on soil microbial community has seldom been investigated.

In this study, loessial soils were treated with four levels of $\mathrm{Cd}$, i.e., $0\left(\mathrm{Cd}_{0}\right), 1.5\left(\mathrm{Cd}_{1.5}\right), 3.0\left(\mathrm{Cd}_{3.0}\right)$ and 6.0 $\left(\mathrm{Cd}_{6.0}\right) \mathrm{mg} \mathrm{Cd} \mathrm{kg}{ }^{-1}$ soil, and two levels of $\mathrm{CO}_{2}$, i.e., $360\left(\mathrm{aCO}_{2}\right)$ and $480\left(\mathrm{eCO}_{2}\right)$ ppm. Soil bacterial and fungal abundance, community structure, $\mathrm{CO}_{2}$ emission, $\mathrm{C}$ and $\mathrm{N}$ were measured to determine how soil $\mathrm{Cd}$ pollution and elevated $\mathrm{CO}_{2}$ separately or in combination could impact soil microbial community and $\mathrm{C}$ and $\mathrm{N}$ accumulation. 

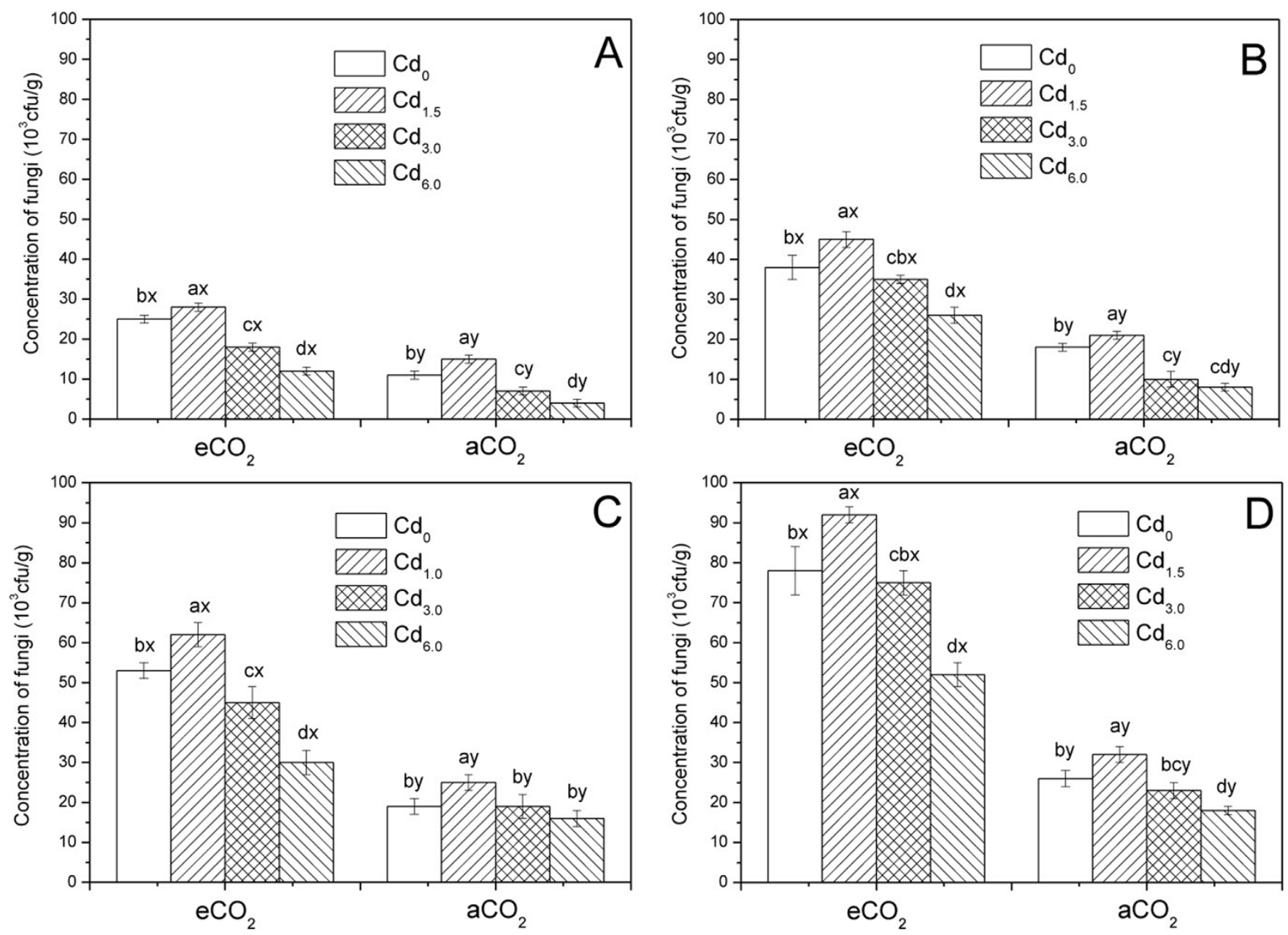

Figure $1 \mid$ Effects of cadmium and $\mathrm{CO}_{2}$ on soil fungal abundance after 2 weeks $(\mathrm{A}), 4$ weeks $(\mathrm{B}), 6$ weeks $(\mathrm{C})$ and 8 weeks $(\mathrm{D})$ under $0\left(\mathrm{Cd}_{0}\right), 1.5\left(\mathrm{Cd}_{1.5}\right)$, $3.0\left(\mathrm{Cd}_{3.0}\right)$ and $6.0\left(\mathrm{Cd}_{6.0}\right) \mathrm{mg} \mathrm{Cd} \mathrm{kg}{ }^{-1}$ soil and ambient $\mathrm{CO}_{2}\left(360 \mathrm{ppm}, \mathrm{aCO}_{2}\right)$ or elevated $\mathrm{CO}_{2}\left(480 \mathrm{ppm}, \mathrm{eCO}_{2}\right)$. Data $(\mathrm{means} \pm \mathrm{SE}, n=3)$ followed by different letters between $\mathrm{Cd}$ treatments for the same $\mathrm{CO}_{2}$ treatment $(\mathrm{a}, \mathrm{b}, \mathrm{c}, \mathrm{d})$ or between $\mathrm{aCO}_{2}$ and $\mathrm{eCO}_{2}$ for the same Cd treatment $(\mathrm{x}, \mathrm{y})$ are significantly different at $P<0.05$ according to Mann-Whitney multiple comparisons.

\section{Results}

Microbial community. The abundance of soil fungi was affected not only by $\mathrm{Cd}$ but also by $\mathrm{CO}_{2}$ concentrations (Fig. 1). Fungal abundance generally linearly increased with incubation time over the eight weeks of $\mathrm{Cd}$ exposure under all treatments. Fungal abundance was much greater under $\mathrm{eCO}_{2}$ than under $\mathrm{aCO}_{2}$, regardless of $\mathrm{Cd}$ levels. Compared to the non-Cd control, fungal abundance was significantly increased under $\mathrm{Cd}_{1.5}$, but decreased under $\mathrm{Cd}_{3.0}$ and $\mathrm{Cd}_{6.0}$, regardless of $\mathrm{CO}_{2}$ levels.

Soil bacterial abundance was gradually decreased with increase of $\mathrm{Cd}$ concentrations. Its abundance was lower under $\mathrm{aCO}_{2}$ than under $\mathrm{eCO}_{2}$ at the same $\mathrm{Cd}$ concentration. Bacterial abundance was decreased after 2 to 4 weeks and was lowest at 4 week over the eight weeks of $\mathrm{Cd}$ exposure under both $\mathrm{aCO}_{2}$ and $\mathrm{eCO}_{2}$ (Fig. 2). But soil bacterial abundance began to increase after 4 weeks and was highest at 8 weeks of incubation.

The triplicate running of DGGE profiles was highly reproducible so only one DGGE profile was displayed (Fig. 3). After 4 weeks of incubation, 10 bands under $\mathrm{eCO}_{2}$ while 8 bands under $\mathrm{aCO}_{2}$ were obviously observed, irrespective of Cd concentrations (left panel in Fig. 3). Among these bands, 4 distinctive bands were generated (the left-towards red arrows in the left panel) and 2 bands were disappeared (the right-towards red arrows in the left panel) under $\mathrm{eCO}_{2}$ than under $\mathrm{aCO}_{2}$. Furthermore, after 8 weeks of incubation, 8 bands under $\mathrm{eCO}_{2}$ while 6 bands under $\mathrm{aCO}_{2}$ were obviously observed, irrespective of $\mathrm{Cd}$ concentrations (right panel in Fig. 3). Among these bands, 3 distinctive bands were generated (the left-towards red arrows in the right panel) and 1 band was disappeared (the righttowards red arrows in the right panel) under eCO $\mathrm{CO}_{2}$ than under $\mathrm{aCO}_{2}$. In addition, there were visual differences in DGGE band width between two incubation durations (4 and 8 weeks), while there seemed no distinctively visual differences between $\mathrm{Cd}_{0}$ and other Cd concentrations (no measurements were done to determine the width). Therefore, the DGGE profiles, e. g., the soil microbial community structure, were altered under $\mathrm{eCO}_{2}$ and cadmium pollution over the 8 weeks of soil incubation.

Soil $\mathrm{C}$ and $\mathrm{N}$ dynamics. The $\mathrm{CO}_{2}$ emission showed a decrease trend with the increase of $\mathrm{Cd}$ concentrations under either $\mathrm{eCO}_{2}$ or $\mathrm{aCO}_{2}$ (Fig. 4). The cumulative soil $\mathrm{CO}_{2}$ effluxes were generally significantly greater under $\mathrm{eCO}_{2}$ than under $\mathrm{aCO}_{2}$ over the 8 weeks incubation, regardless of Cd treatment levels.

Concentrations of soil $\mathrm{C}$ and $\mathrm{N}$ were greater in soils treated with higher concentrations of $\mathrm{Cd}$ at both $\mathrm{CO}_{2}$ levels. Significantly higher concentrations of soil $\mathrm{C}$ and $\mathrm{N}$ were observed under $\mathrm{aCO}_{2}$ than under $\mathrm{eCO}_{2}$, regardless of $\mathrm{Cd}$ treatments (Fig. $5 \mathrm{a}$ and $5 \mathrm{~b}$ ).

\section{Discussion}

Due to excessive emission of industrial waste, wastewater irrigation and serious abuse of chemical fertilizers and pesticides, numerous 

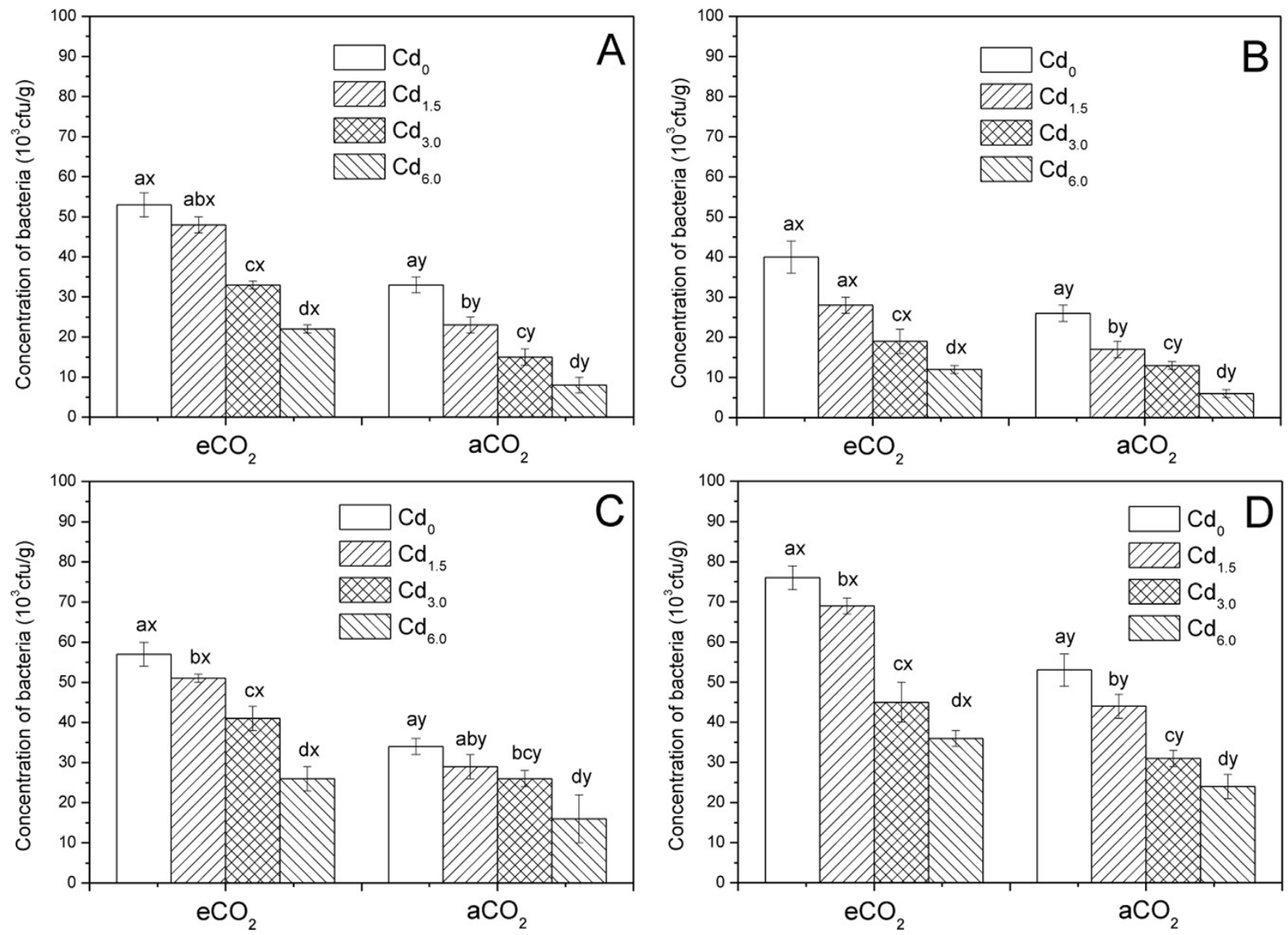

Figure $2 \mid$ Effects of cadmium and $\mathrm{CO}_{2}$ on soil bacterial abundance after 2 weeks (A), 4 weeks (B), 6 weeks $(\mathrm{C})$ and 8 weeks $(\mathrm{D})$ under 0 (Cd 0 ), 1.5 $\left(\mathrm{Cd}_{1.5}\right), 3.0\left(\mathrm{Cd}_{3.0}\right)$ and $6.0\left(\mathrm{Cd}_{6.0}\right) \mathrm{mg} \mathrm{Cd} \mathrm{kg}{ }^{-1}$ soil and ambient $\mathrm{CO}_{2}\left(360 \mathrm{ppm}, \mathrm{aCO}_{2}\right)$ or elevated $\left.\mathrm{CO}_{2}(480 \mathrm{ppm}, \mathrm{eCO})\right)$. Data $(\mathrm{means} \pm \mathrm{SE}, n=3)$ followed by different letters between Cd treatments for the same $\mathrm{CO}_{2}$ treatment $(\mathrm{a}, \mathrm{b}, \mathrm{c}, \mathrm{d})$ or between $\mathrm{aCO}_{2}$ and eCO $\mathrm{C}_{2}$ for the same Cd treatment $(\mathrm{x}, \mathrm{y})$ are significantly different at $P<0.05$ according to Mann-Whitney multiple comparisons.

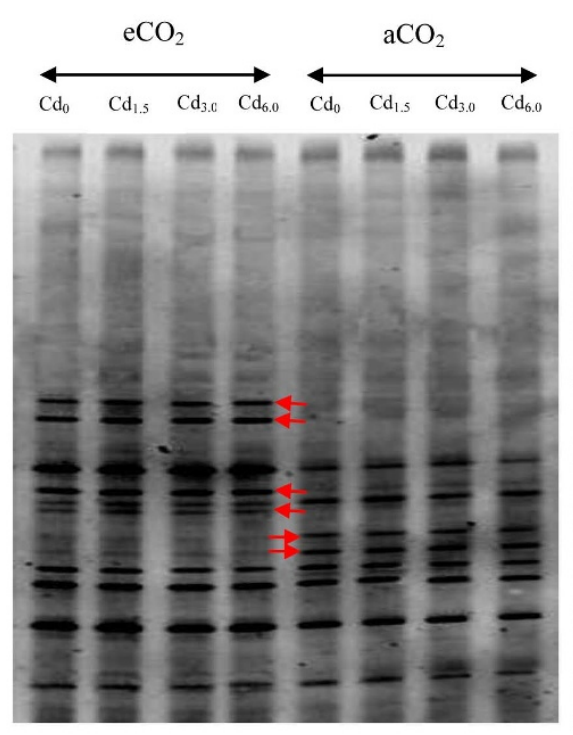

4 Weeks

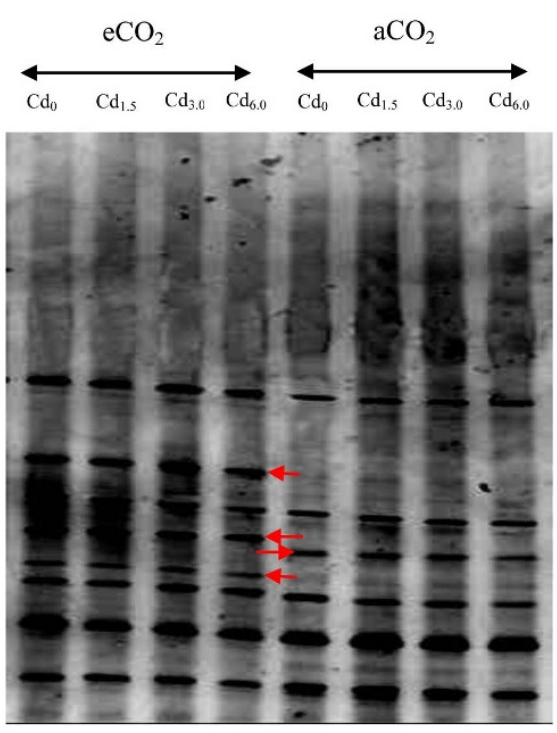

8 Weeks

Figure 3 Effects of cadmium and $\mathrm{CO}_{2}$ on soil bacterial community structure (DGGE profiles of PCR products from 16S rDNA extractions) after 4 weeks and 8 weeks under $0\left(\mathrm{Cd}_{0}\right), 1.5\left(\mathrm{Cd}_{1.5}\right), 3.0\left(\mathrm{Cd}_{3.0}\right)$ and $6.0\left(\mathrm{Cd}_{6.0}\right) \mathrm{mg} \mathrm{Cd} \mathrm{kg}{ }^{-1}$ soil and ambient $\mathrm{CO}_{2}\left(360 \mathrm{ppm}^{\mathrm{aCO}}\right)_{2}$ or elevated CO $\mathrm{CO}_{2}(480 \mathrm{ppm}$, $\left.\mathrm{eCO}_{2}\right)$. Red arrow showed differences in DGGE bands between $\mathrm{aCO}_{2}$ and $\mathrm{eCO}_{2}$ treatments. 

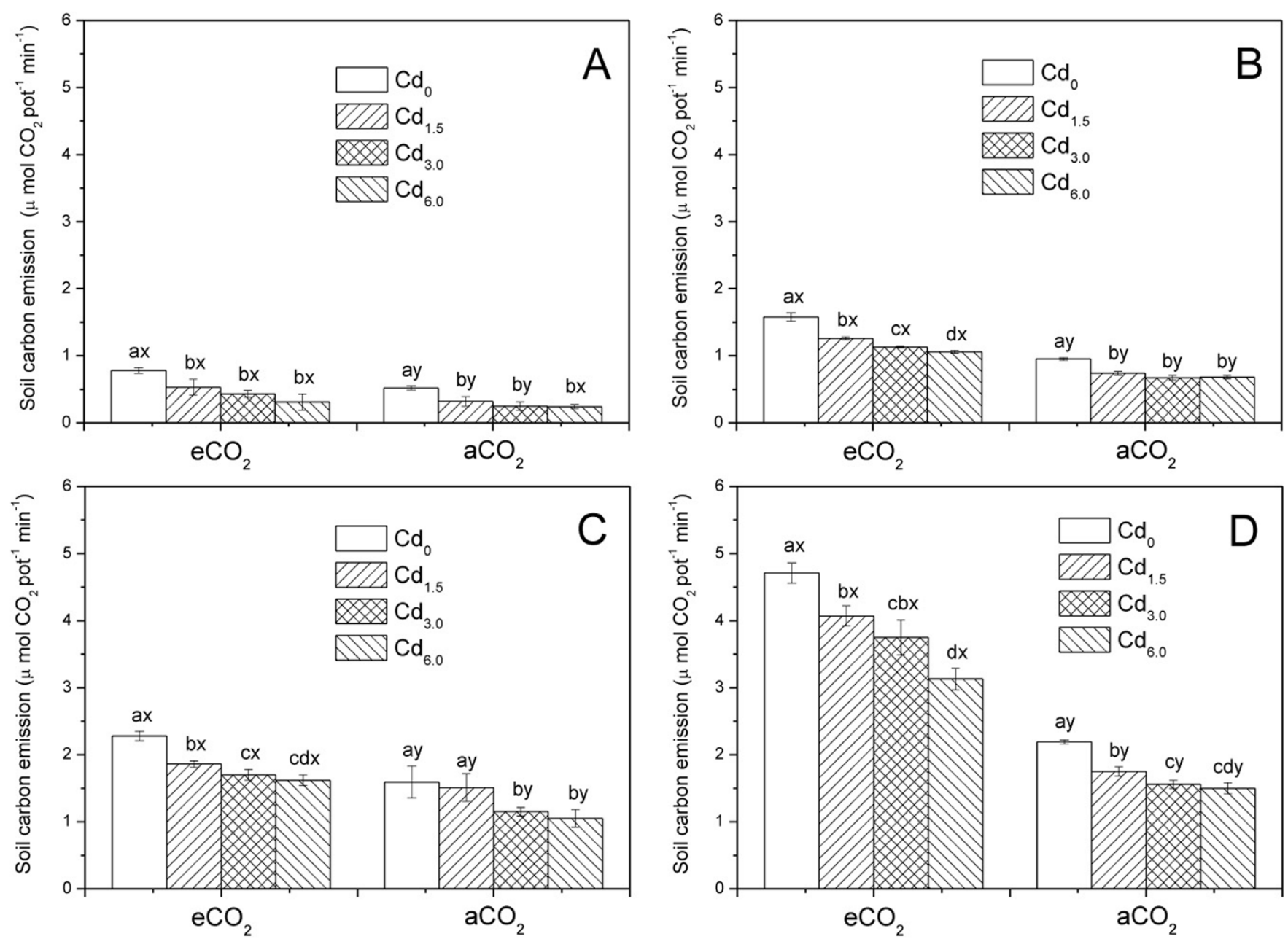

Figure $4 \mid$ Effects of cadmium and $\mathrm{CO}_{2}$ on soil cumulative carbon emission after 2 weeks (A), 4 weeks (B), 6 weeks (C) and 8 weeks (D) under 0 (Cd $\mathrm{Cd}_{0}$ ), $1.5\left(\mathrm{Cd}_{1.5}\right), 3.0\left(\mathrm{Cd}_{3.0}\right)$ and $6.0\left(\mathrm{Cd}_{6.0}\right) \mathrm{mg} \mathrm{Cd} \mathrm{kg}{ }^{-1}$ soil and ambient $\mathrm{CO}_{2}\left(360 \mathrm{ppm}, \mathrm{aCO}_{2}\right)$ or elevated $\mathrm{CO}_{2}(480 \mathrm{ppm}, \mathrm{eCO})$. Data $(\mathrm{means} \pm \mathrm{SE}$, $n=3$ ) followed by different letters between Cd treatments for the same $\mathrm{CO}_{2}$ treatment (a, b, c, d) or between aCO${ }_{2}$ and $\mathrm{eCO}_{2}$ for the same $\mathrm{Cd}_{\text {treatment }}$ $(\mathrm{x}, \mathrm{y})$ are significantly different at $P<0.05$ according to Mann-Whitney multiple comparisons.

heavy metals have been released into the environment ${ }^{16}$. One fifth of total cultivated land in China was polluted by heavy metals, such as arsenic (As), cadmium (Cd), chromium $(\mathrm{Cr})$ and lead $(\mathrm{Pb})^{17}$. Heavy metal pollution has been a threat to the earth system. Previous studies have showed that either short-term or long-term exposure to heavy metals could result in changing of soil microbial communities, or decrease in diversity and activities ${ }^{12-15}$. Moreover, fungi are more tolerant to heavy metals than bacteria ${ }^{18}$. Our results in loessial soil were consistent with those previous studies ${ }^{18}$. Bacteria were more sensitive to Cd stress than fungi because the low $(1.5 \mathrm{mg} \mathrm{Cd} \mathrm{kg}$ soil) treatment restrained the bacteria reproduction but improved fungal reproduction (Fig. 1 and 2). With the increase of Cd concentrations, the fungal and bacterial abundance were gradually decreased under normal $\mathrm{CO}_{2}$ (Fig. 1 and 2). Moreover, the alteration of DGGE profiles might provide direct evidence that the microbial communities might have been influenced by elevated $\mathrm{CO}_{2}$, but not by cadmium pollution at the tested $\mathrm{Cd}$ concentrations (Fig. 3). Consequently, no matter whether the soil was incubated under the ambient $\mathrm{CO}_{2}$ or the elevated $\mathrm{CO}_{2}$ concentration, soil respiration was restrained while concentrations of soil $\mathrm{C}$ and $\mathrm{N}$ were increased (Fig. 4 and 5), indicating that $\mathrm{Cd}$ pollution could alter soil biogeochemical cycling.

Elevated $\mathrm{CO}_{2}$ have various impacts on biogeochemical processes in terrestrial ecosystems. There were some different viewpoints on the effect of elevated $\mathrm{CO}_{2}$ on soil microbial abundance. For instance, in free-air $\mathrm{CO}_{2}$ enrichment experiment no significant changes were observed in the relative abundance or composition of fungi $1^{19}$. On the contrary, the fungal biomass in a chaparral ecosystem was significantly increased under $550 \mathrm{ppm}$ elevated $\mathrm{CO}_{2}{ }^{20}$, and the relative abundance of fungi in a scrub-oak ecosystem was greater under elevated $\mathrm{CO}_{2}$ than under ambient $\mathrm{CO}_{2}{ }^{3}$. Elevated $\mathrm{CO}_{2}$ could stimulate microbial growth, especially bacteria, and lead to substantial changes in the activity and structure of soil microbial communities ${ }^{21}$. Recently, analyses of 16S rRNA genes showed that soil microbial community structures were significantly changed by elevated $\mathrm{CO}_{2}{ }^{22}$. Our experiments also demonstrated the bacterial and fungal abundance were increased by $\mathrm{eCO}_{2}$ regardless of $\mathrm{Cd}$ levels. Compared with the same $\mathrm{Cd}$ concentration, elevated $\mathrm{CO}_{2}$ significantly altered the bacterial and fungal abundance, the bacterial DNA brand, and decreased the concentrations of soil $\mathrm{C}$ and $\mathrm{N}$, resulting in changes in soil microbial community and soil biogeochemical element cycling. These results support that elevated $\mathrm{CO}_{2}$ could result in a loss of soil carbon ${ }^{4}$.

Elevated $\mathrm{CO}_{2}$ and $\mathrm{Cd}$ exhibited opposite effects on soil microbial communities. Cd pollution restrained microorganism's growth and high concentration of $\mathrm{Cd}$ could decrease microbial biomass and activities. As a result, less SOM could be utilized and thus less $\mathrm{CO}_{2}$ was released from soil, which in turn had more $\mathrm{C}$ and $\mathrm{N}$ retained in the soil. Moreover, with an increase of Cd concentration, the negative effect was more obvious. However, soil microbial relative abundances 

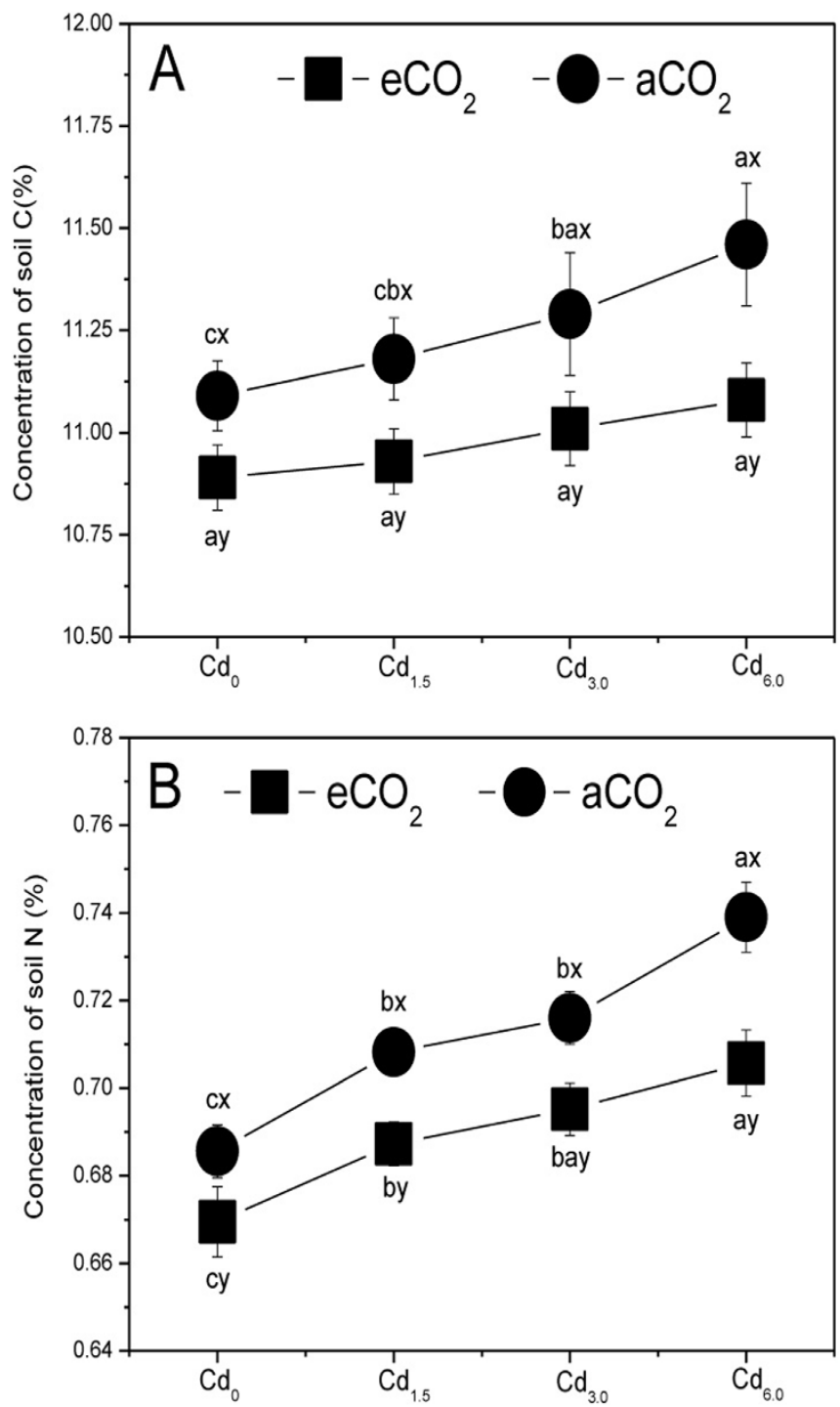

Figure 5 Effects of 8-weeks cadmium and $\mathrm{CO}_{2}$ treatments on soil carbon (A) and nitrogen $(\mathrm{B})$ concentrations under $0\left(\mathrm{Cd}_{0}\right), 1.5\left(\mathrm{Cd}_{1.5}\right), 3.0\left(\mathrm{Cd}_{3.0}\right)$ and $6.0\left(\mathrm{Cd}_{6.0}\right) \mathrm{mg} \mathrm{Cd} \mathrm{kg}{ }^{-1}$ soil and ambient $\mathrm{CO}_{2}\left(360 \mathrm{ppm}, \mathrm{aCO}_{2}\right)$ or elevated $\mathrm{CO}_{2}\left(480 \mathrm{ppm}, \mathrm{eCO}_{2}\right)$. Data (means $\pm \mathrm{SE}, n=3$ ) followed by different letters between $\mathrm{Cd}$ treatments for the same $\mathrm{CO}_{2}$ treatment $(\mathrm{a}, \mathrm{b}, \mathrm{c}$, d) or between $\mathrm{aCO}_{2}$ and $\mathrm{eCO}_{2}$ for the same Cd treatment (x,y) are significantly different at $P<0.05$ according to Mann-Whitney multiple comparisons.

and activities of soil carbon-degrading enzymes in soils exposed to an elevated $\mathrm{CO}_{2}$ might have been increased, leading to an enhanced degradation of soil organic matter than soils exposed to ambient $\mathrm{CO}_{2}$, which in turn consumed more $\mathrm{C}$ and $\mathrm{N}$ in soil. Therefore, a combined effect of $\mathrm{Cd}$ and $\mathrm{eCO}_{2}$ could display antagonisms on terrestrial $\mathrm{C}$ pool by altering soil microbial community.

In conclusion, higher Cd exposure to soil could lead to a decrease of both bacterial and fungal abundance, and hence an increasing soil $\mathrm{C}$ and $\mathrm{N}$ concentrations. Meanwhile, elevated $\mathrm{CO}_{2}$ could alter microbial communities and lead to an increase of soil $\mathrm{C}$ emission, resulting in a decrease in soil $\mathrm{C}$ and $\mathrm{N}$ concentrations. These results suggest that $\mathrm{eCO}_{2}$ could stimulate, while Cd pollution could restrain, microbial reproduction and $\mathrm{C}$ decomposition with the restraint effect alleviated by $\mathrm{eCO}_{2}$. Nevertheless, more research is warranted on the combined effects of $\mathrm{Cd}$ pollution and elevated $\mathrm{CO}_{2}$ on the dynamics of soil C.

\section{Methods}

Soil characteristics. Loessial soils at $0-10 \mathrm{~cm}$ depth were collected from a field after maize harvest in a suburban of Xi'an, Shaanxi, China $\left(34^{\circ} 44^{\prime} \mathrm{N}, 109^{\circ} 49^{\prime} \mathrm{E}\right)$.

According to Pang et al. ${ }^{23}$, the soil $\mathrm{pH}$ was 8.3 , moisture was $7.8 \%$, soil SOC was $8.9 \mathrm{~g}$ $\mathrm{C} \mathrm{kg}^{-1}$ and $\mathrm{CaCO}_{3}$ was $30.11 \mathrm{~g} \mathrm{~kg}^{-1}$.

Experiment design. The experiment consisted of four $\mathrm{Cd}$ and two $\mathrm{CO}_{2}$ treatments in a completely randomized arrangement. The four Cd treatments were $0\left(\mathrm{Cd}_{0}\right), 1.5$ $\left(\mathrm{Cd}_{1.5}\right)$, $3.0\left(\mathrm{Cd}_{3.0}\right)$ or $6.0 \mathrm{mg} \mathrm{Cd} \mathrm{kg}{ }^{-1}$ soil $\left(\mathrm{Cd}_{6.0}\right)$ and the two $\mathrm{CO}_{2}$ treatments were ambient $\left(360 \mathrm{ppm}, \mathrm{aCO}_{2}\right)$ or elevated $\left(480 \mathrm{ppm}, \mathrm{eCO}_{2}\right)$. Each treatment had three replicates, for a total of 24 replicates. The soil was put in 24 growth pots. Each pot (15 cm diameter and $10 \mathrm{~cm}$ height) contained $1.0 \mathrm{~kg}$ soil. The $\mathrm{CO}_{2}$ concentrations were monitored and controlled by a meter (output flux: $25 \mathrm{~L} \mathrm{~min}^{-2}, 15 \mathrm{MPa}$ pressure; Shanghai Yichuan Meter Co., Shanghai, China). Cd was applied as $\mathrm{CdCl}_{2} \cdot 2.5 \mathrm{H}_{2} \mathrm{O}$ (99\%, Tianjin Fuchen Chemical Co., Tianjin, China), which was firstly dissolved in distilled water and then thoroughly mixed with soil. The Cd-containing soils were continuously incubated under $25 \pm 1{ }^{\circ} \mathrm{C}$ and $70 \%$ of relative humidity over 8 weeks in a plant growth chamber.

Soil microbial community structure. The number of bacteria and fungi was counted using the plate counting technique ${ }^{24}$. Briefly, approximately $10 \mathrm{~g}$ soils from each pot were putted into a $300 \mathrm{ml}$ Erlenmeyer flask containing $90 \mathrm{ml}$ sterilized potassium phosphate buffer $\left(0.35 \mathrm{~g} \mathrm{KH}_{2} \mathrm{PO}_{4}, 0.65 \mathrm{~g} \mathrm{~K}_{2} \mathrm{HPO}_{4}\right.$ and $0.10 \mathrm{~g} \mathrm{MgSO}_{4}$ in 1.0 liter water), centrifuged at $250 \mathrm{rpm}$ for $15 \mathrm{~min}$ and the soil extraction solution was then diluted into 100 -fold. Control plates minus soil suspensions were used to check potential contamination. The total number of bacteria was cultured with an agar medium (including $5 \mathrm{~g}$ beef, $10 \mathrm{~g}$ peptone, $5 \mathrm{~g} \mathrm{NaCl}, 20 \mathrm{~g}$ agar and $0.1 \mathrm{~g}$ cycloheximide per $1,000 \mathrm{ml}$ distilled water) for $48 \mathrm{~h}$ at $37^{\circ} \mathrm{C}$. The total number of fungi was cultured with an agar medium (including $10 \mathrm{~g}$ glucose, $5 \mathrm{~g}$ peptone, $1 \mathrm{~g}$ $\mathrm{KH}_{2} \mathrm{PO}, 0.5 \mathrm{~g} \mathrm{MgSO}_{4} \cdot 7 \mathrm{H}_{2} \mathrm{O}, 20 \mathrm{~g}$ agar and $0.1 \mathrm{~g}$ chloramphenicol per $1,000 \mathrm{ml}$ distilled water) for $72 \mathrm{~h}$ at $25^{\circ} \mathrm{C}$. The colony concentrations were expressed as colonyforming units per gram soil (CFU/g) ${ }^{24}$.

DNA extraction and PCR-DGGE analysis. Analyses of bacterial community structure were performed with incubated soils at week 4 and week 8 , respectively. Using a Fast DNA Spin Kit (Bio 101, USA), the extraction of soil bacterial DNA was tripled (1.0 g soil each) from each treatment according to the manufacturer's beadbeating procedure. The yield and quality of extracted DNA was validated by the $1.0 \%$ $(\mathrm{w} / \mathrm{v})$ agarose gel electrophoresis with ethidium bromide staining. The bacterial 16S rDNA genes were amplified with the primer EUB341F ( $5^{\prime}$-CCT ACG GGA GGC AGC AG-3') with a GC clamp (CGC CCG CCG CGC CCC GCG CCC GTC CCG CCG CCC CCG CCC G) at the $5^{\prime}$ end and the premier EU500R ( $5^{\prime}$-GTA TTA CCG CGG CTG CTG G-3' $3^{\prime 25}$. Using $50 \mu \mathrm{l}$ reaction volumes the PCR amplification was carried out with an iCycler Thermal Cycler (Bio-Rad, USA). A final $50 \mu \mathrm{l}$ reaction mixture contained 1-10 ng DNA extracts as template, $5 \mu$ of $10 \times$ PCR buffer (minus $\mathrm{Mg}^{2+}$ ), $15 \mathrm{pmol}$ of each primer, $1.25 \mu \mathrm{l}$ unit Taq polymerase, $200 \mu \mathrm{mol}$ deoxyribonucleoside triphosphate, and $3 \mu \mathrm{MgCl}_{2}(25 \mathrm{mmol})$. A touchdown temperature profile was applied as the annealing temperature decreased from $65^{\circ} \mathrm{C}$ to $55^{\circ} \mathrm{C}$ after 20 cycles with a $0.5^{\circ} \mathrm{C}$ decline from each cycle, and then the mixture was kept at $55^{\circ} \mathrm{C}$ for further 10 cycles. An aliquot of $5 \mathrm{ml}$ PCR products was then run by $1.0 \%$ agarose gel electrophoresis with ethidium bromide staining prior to the denaturing gradient gel electrophoresis (DGGE), which was conducted with a BioRad Dcode ${ }^{\mathrm{TM}}$ Universal Mutation Detection System (Bio-Rad, USA). The generated PCR product was loaded on $0.8 \mathrm{~mm}$ thick polyacrylamide gel (10\% acrylamide/ bisacrylamide, $\mathrm{w} / \mathrm{v}=37.5 / 1)$ under a $30 \%$ to $50 \%$ of urea and formamide $(100 \%$ corresponds to $7 \mathrm{~mol}$ urea and $40 \%$ formamide, w/v) denaturing gradient that was increased in the electrophoresis running direction. The electrophoresis was run for $5 \mathrm{~h}$ under $60^{\circ} \mathrm{C}$ and $150 \mathrm{~V}$. After the run, the gels were stained with $1 \times$ TAE (containing $0.5 \mathrm{mg} \mathrm{ml}^{-1}$ ethidium bromide) for $20 \mathrm{~min}$, rinsed with distilled water thoroughly, and then photographed.

Measurements of soil total carbon and nitrogen. Soils from all 8-week incubation pots were air-dried to a constant weight and sieved through $1.0 \mathrm{~mm}$ mesh. Total carbon and nitrogen were determined according to the dichromate oxidation ${ }^{26}$ and the $\mathrm{H}_{2} \mathrm{SO}_{4}$ titrate method ${ }^{26}$, respectively.

Soil $\mathrm{CO}_{2}$ efflux measurements. After incubation for 2, 4, 6 and 8 weeks, the pot was placed into a PVC (polyvinyl chloride) collar (14.5 cm height and $20.3 \mathrm{~cm}$ inside diameter) and the bottom was completely sealed. Soil $\mathrm{CO}_{2}$ efflux rates ( $\mu$ mol $\mathrm{CO}_{2}$ pot $^{-1} \mathrm{~min}^{-1}$ ) between 12:00 pm and 15:00 pm were quantified by a LI-8100 soil CO flux system (LI-COR Inc., Lincon, NE, USA), which was equipped with a portable chamber (Model 8100-103) being placed into the PVC collar. The $\mathrm{CO}_{2}$ efflux rate was then automatically calculated from exponential regression of increasing $\mathrm{CO}_{2}$ concentrations over 3-min duration. Each measurement for a pot was repeated 3 times and 3 repetition experiments were performed in one day.

Data analysis. Data (means $\pm \mathrm{SE}$ ) were subjected to one-way analysis of variance (ANOVA) and significant differences between treatments were compared using the Mann-Whitney multiple comparison at $P<0.05$. Statistical analyses were performed using the SPSS16.0 (SPSS Inc., Chicago, IL, USA). 
1. Meinshausen, M. et al. The RCP greenhouse gas concentrations and their extensions from 1765 to 2300. Climatic Change 109, 213-241 (2011).

2. Oelkers, E. H. \& Cole, D. R. Carbon dioxide sequestration: a solution to the global problem. Elements 4, 305-310 (2008).

3. Luo, Y., Hui, D. \& Zhang, D. Elevated $\mathrm{CO}_{2}$ stimulates net accumulations of carbon and nitrogen in land ecosystems: a meta-analysis. Ecology 87, 53-63 (2006).

4. Carney, M. C., Hungate, B. A., Drake, B. G. \& Megonigal, J. P. Altered soil microbial community at elevated $\mathrm{CO}_{2}$ leads to loss of soil carbon. Proc. Natl. Acad. Sci. USA 104, 4990-4995 (2007).

5. Gruber, N. \& Galloway, J. N. An Earth-system perspective of the global nitrogen cycle. Nature 451, 293-296 (2008).

6. Heimann, M. \& Reichstein, M. Terrestrial ecosystem carbon dynamics and climate feedbacks. Nature 451, 289-292 (2008).

7. Jossi, M. et al. How elevated $\mathrm{CO}_{2}$ modifies total and metabolically active bacterial communities in the rhizosphere of two perennial grasses grown under field conditions. FEMS Microbiol. Ecol. 55, 339-350 (2006).

8. Gruter, D., Schmid, B. \& Brandl, H. Influence of plant diversity and elevated atmospheric carbon dioxide levels on belowground bacterial diversity. BMC Microbiol. 6, 68-75 (2006).

9. Lesaulnier, C. et al. Elevated atmospheric $\mathrm{CO}_{2}$ affects soil microbial diversity associated with trembling aspen. Environ. Microbiol. 10, 926-941 (2008).

10. Austin, E. E., Castro, H. F., Sides, K. E., Schadt, C. W. \& Classen, A. T. Assessment of 10 years of $\mathrm{CO}_{2}$ fumigation on soil microbial communities and function in a sweetgum plantation. Soil Biol. Biochem. 41, 514-520 (2009).

11. Duenas, C., Fernandez, M. C., Carretero, J., Liger, E. \& Perez, M. Emissions of $\mathrm{CO}_{2}$ from some soils. Chemosphere 30, 1875-1889 (1995).

12. Edwards, C. et al. Microbiological processes in the terrestrial carbon cycle: methane cycling in peat. Atmos. Environ. 32, 3247-3255 (1998).

13. Rosswall, T. Microbiological regulation of the biogeochemical nitrogen cycle Plant and Soil 67, 15-34 (1982).

14. Shen, G. Q. et al. Influence of phenanthrene on cadmium toxicity to soil enzymes and microbial growth. Environ. Sci. Pollut. Res. 12, 259-263 (2005).

15. McGrath, S. P., Zhao, F. J. \& Lombi, E. Plant and rhizosphere processes involved in phytoremediation of metal-contaminated soils. Plant Soil 232, 207-214 (2001).

16. Nagajyoti, P. C., Lee, K. D. \& Sreekanth, T. V. M. Heavy metals, occurrence and toxicity for plants: a review. Environ. Chem. Lett. 8, 199-216 (2010).

17. State Environmental Protection Administration. Investigation report of ecoenvironmental situation in China's Mideast regions. Environ. Prot. (in Chinese) $\mathbf{8}$ 3-8 (2003).

18. Oliveira, A. \& Pampulha, M. E. Effects of long-term heavy metal contamination on soil microbial characteristics. J. Biosci. Bioeng. 102, 157-161 (2006).

19. Chung, H., Zak, D. \& Lilleskov, E. Fungal community composition and metabolism under elevated $\mathrm{CO}_{2}$ and $\mathrm{O}_{3}$. (Springer-Verlag GMBH, Germany), pp. 143-154 (2006)
20. Lipson, D. A., Wilson, R. F. \& Oechel, W. C. Effects of elevated atmospheric $\mathrm{CO}_{2}$ on soil microbial biomass, activity, and diversity in a chaparral ecosystem. Appl. Environ. Microbiol. 71, 8573-8580 (2005).

21. Adair, E. C., Reich, P. B., Hobbie, S. E. \& Knops, M. H. Interactive effects of time, $\mathrm{CO}_{2}, \mathrm{~N}$, and diversity on total belowground carbon allocation and ecosystem carbon storage in a grassland community. Ecosystems 12, 1037-1052 (2009).

22. He, Z. et al. Metagenomic analysis reveals a marked divergence in the structure of belowground microbial communities at elevated $\mathrm{CO}_{2}$. Ecol. Lett. 13, 564-575(2010).

23. Pang, J. L., Qiu, H. Y., Huang, C. C., Cha, X. C. \& Zhang, X. Comparison of micromorphological features of two agricultural cultivated soils in Guanzhong areas, Shaanxi province, China. Agr. Sci. China. 6, 1089-1098 (2007).

24. Zhang, J. Z. Microbial Taxology (in Chinese). (Fudan University Press, Shanghai, China, 1990)

25. Muyzer, G., de Waal, E. C. \& Uitterlinden, A. G. Profiling of complex microbial populations by denaturing gradient gel electrophoresis analysis of polymerase chain analysis of polymerase chain. Appl. Environ. Microbiol. 59, 695-700 (1993).

26. Bao, S. D. Soil and Agricultural Chemistry Analysis (in Chinese). (China Agriculture Press, Beijing, 2002).

\section{Acknowledgments}

This study was supported by National Sciences Foundation of China (31070364). We thank Dr Jin Zhao kindly provided the LI- 8100 soil $\mathrm{CO}_{2}$ flux system.

\section{Author contributions}

Y.C. designed experiments, conducted $\mathrm{CO}_{2}$ emission measurements, data analyses and wrote the manuscript. Q.L. performed experiments in soil carbon and nitrogen. Y.L. performed experiments in DGGE profiles. F.J. did experiments in bacterial and fungal abundance. X.H. analyzed data and rewrote the manuscript. All authors reviewed the manuscript

\section{Additional information}

Competing financial interests: The authors declare no competing financial interests.

How to cite this article: Chen, Y.P., Liu, Q., Liu, Y.J., Jia, F.A. \& He, X.H. Responses of soil microbial activity to cadmium pollution and elevated $\mathrm{CO}_{2}$. Sci. Rep. 4, 4287; DOI:10.1038/ srep04287 (2014)

\section{(i) (2) This work is licensed under a Creative Commons Attribution-}

NonCommercial-ShareAlike 3.0 Unported license. To view a copy of this license, visit http://creativecommons.org/licenses/by-nc-sa/3.0 